\title{
Huffmanela paronai sp. n. (Nematoda: Trichosomoididae), a new parasite from the skin of swordfish Xiphias gladius in the Ligurian Sea (Western Mediterranean)
}

\author{
František Moravec $^{1}$ and Fulvio Garibaldi ${ }^{2}$ \\ ${ }^{1}$ Institute of Parasitology, Academy of Sciences of the Czech Republic, Branišovská 31, 37005 České Budějovice, Czech \\ Republic; \\ ${ }^{2}$ Dipartimento per lo Studio del Territorio e delle sue Risorse (DIP.TE.RIS.), Laboratori di Biologia Marina ed Ecologia \\ Animale, Università di Genova, Via Balbi 5, 16126 Genova, Italy
}

Key words: parasitic nematode, Huffmanela, epidermis, fish, Xiphias, Ligurian Sea, Italy

\begin{abstract}
A new species of trichosomoidid nematode, Huffmanela paronai sp. n., is established on the basis of its egg morphology and biological characters. The dark-shelled, embryonated eggs of this histozoic parasite occur in masses in the epidermis of the swordfish Xiphias gladius L. (Xiphiidae, Perciformes) from the Ligurian Sea in northern Italy. The eggs are concentrated in groups appearing as black spots in the skin of the fish host, being distributed mainly on the lower part of its body (lower jaw, gill covers, pectoral, anal and caudal fins, lower half of body). The parasite's eggs are characterised mainly by their shape and markedly small size $(48-51 \times 21-24 \mu \mathrm{m})$, an aspinose surface, relatively small polar plugs, and thick egg wall $(3 \mu \mathrm{m})$. This is the first Huffmanela species reported from fish in Europe.
\end{abstract}

During studies on the fishery and biology of the swordfish, Xiphias gladius L., carried out by the junior author (F. Garibaldi) since 1990 in the Ligurian Sea, Italy, unusual black spots were noticed on the skin of some fish. Closer microscopical examination showed that they were formed by masses of dark-shelled trichinelloid eggs typical of the nematode genus Huffmanela Moravec, 1987, located in the fish epidermis. The morphological structure and measurements of these eggs, as well as the host type and the site of infection, showed that they undoubtedly represented an undescribed species of this genus.

Since all but one species of Huffmanela, comprising histozoic parasites of fishes, have been described from their eggs only, we consider it reasonable to establish this new species on the basis of its egg morphology and biological characters, despite the lack of conspecific adult nematodes. This is in accordance with the International Code of Zoological Nomenclature.

\section{MATERIALS AND METHODS}

The swordfishes ( $X$. gladius) were caught by the professional fishery in the Ligurian Sea (the fishing season goes from June to November-December). Samples of swordfish skin containing nematode eggs were fixed in $10 \%$ formalin. All attempts to find adult nematodes were unsuccessful. For light microscopy, the eggs were cleared with glycerine. Drawings were made with the aid of a Zeiss microscope drawing attachment and microphotographs with an Aristoplan photomicroscope. After examination, eggs were stored in $70 \%$ ethanol or mounted as preparations in glycerine-jelly. For histological examination, the material was processed by a routine paraffin technique, sectioned at $5 \mu \mathrm{m}$, and stained with Harris' haematoxylin and eosin. All measurements are in $\mu \mathrm{m}$, unless otherwise stated. Type materials have been deposited in the Museo Civico di Storia Naturale in Genoa, Italy and in the Institute of Parasitology, Academy of Sciences of the Czech Republic (ASCR), in České Budějovice, Czech Republic.

\section{DESCRIPTION}

Huffmanela paronai $\mathrm{sp} . \mathrm{n}$.

Figs. 1-3

Eggs $(\mathrm{n}=50)$ : Advanced eggs dark-brown to black, elongate-oval, with two-layered shell, inner layer thin, light in colour, outer layer dark, with smooth surface. Polar plugs small, distinctly protruding, light-coloured, height of polar plug 6, width 6-7, height of its protruding part 1-3. Size of eggs including polar plugs $48-51 \times 21-24$, length of egg proper without polar plugs 45-48, egg wall thick (3). Whole egg including polar plugs covered by thin transparent envelope (thickness 1-3) with smooth surface or envelope may be absent. Eggs contain already fully formed larva.

Less developed eggs (not yet containing larva) with colourless hyaline shell distinctly smaller than more advanced eggs, being covered by thin transparent envelope.

Adults: Unknown.

T y p e h o s t: Swordfish, Xiphias gladius Linnaeus, 1758 (Xiphiidae, Perciformes).

$\mathrm{S}$ i t e of in fe ct i o $\mathrm{n}$ : Epidermis (mainly on lower jaw, gill covers, pectoral, anal and caudal fins and lower half of body - see Figs. 2 C, D and 3). 

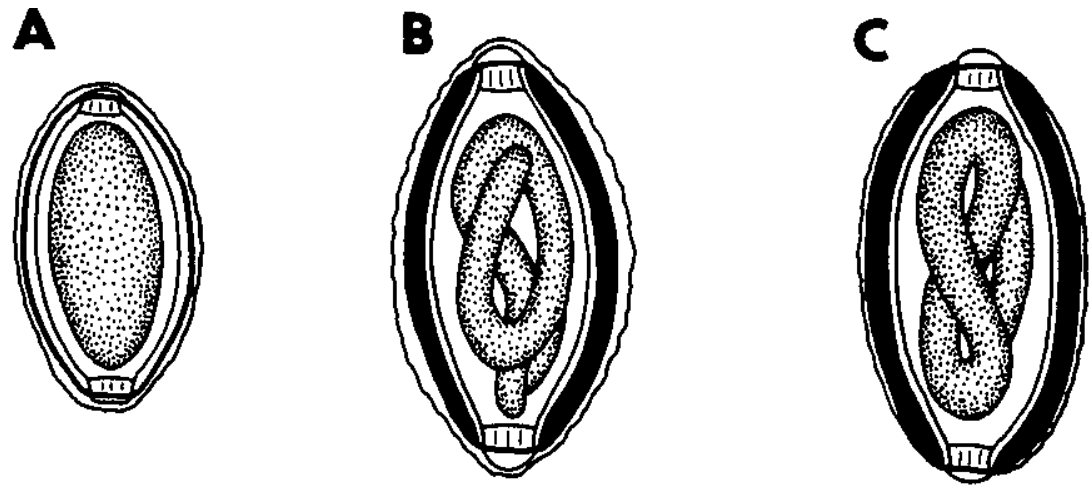

Fig. 1. Huffmanela paronai sp. n., eggs from the epidermis of Xiphias gladius. A - less developed, unembryonated egg; B, C advanced eggs with differently developed transparent envelope on surface; $\mathbf{D}$ - advanced egg with indistinct superficial envelope. Scale bar in $\mathrm{mm}$.

T y p e 1 o c a 1 i t y : Ligurian Sea, Italy (type material collected in 1999).

P r e v a 1 e $\mathrm{n} \mathrm{c}$ e : $4.4 \%$ of the total swordfish caught and landed in Sanremo harbour (recorded in 135 out of 3098 fish).

E $\mathrm{t} \mathrm{y} \mathrm{mo} \mathrm{log} \mathrm{y}$ : This species is named in honour of a distinguished Italian helminthologist Corrado Parona (1848-1922), the director of the Institute of Zoology of the Genoa University during the period 1883-1922, who contributed greatly to the recognition of nematodes (particularly trichinelloids) and other helminths.

De position of ty p material (syntypes): Museo Civico di Storia Naturale "G. Doria" in Genoa (Cat. No. MSNG 50232) and Institute of Parasitology, ASCR, in České Budějovice (Cat. No. N-763).

\section{DISCUSSION}

The genus Huffmanela includes little-known histozoic parasites of various tissues (skin, mucosa of gill arches, musculature, swimbladder wall, serosa covering intestine) of marine and less often freshwater fishes (Moravec et al. 1998). At present it comprises seven species, five of them described from their eggs only. Adult nematodes of this genus have so far been described only in H. huffmani Moravec, 1987, a swimbladder parasite of freshwater centrarchids in Texas (Huffman and Moravec 1988). Nematode specimens of uncertain developmental stage of $H$. shikokuouensis Moravec, Koudela, Ogawa et Nagasawa, 1998, a parasite of the musculature of the marine tetraodontiform fish Stephanolepis cirrhifer (Temminck et Schlegel) in Japan, were found in histological sections as intracellular parasites by Moravec et al. (1998).

Other Huffmanela species, known only from their eggs include: H. carcharhini (MacCallum, 1925) (syn. Capillaria spinosa MacCallum, 1926) (type species) from the skin and the mucosa of gill arches of requiem sharks from the Atlantic Ocean off the coast of the southern USA (MacCallum 1925, 1926, Moravec 1987, Moravec and Campbell 1991), H. banningi Moravec, 1987 from the musculature of the pleuronectiform fish Cynoglossus browni Chabanaud from the Atlantic Ocean off the coast of Senegal (Priebe 1976; van Banning 1980; Moravec 1987; Moravec and Campbell 1991), H. schouteni Moravec et Campbell, 1991 from the intestinal serosa of flying fishes in Curaçao (Schouten et al. 1968, Suriel-Smeets and Schouten 1972, Moravec and Campbell 1991), H. japonica Moravec, Koudela, Ogawa et Nagasawa, 1998 from the musculature of the mullid fish Upeneus bensasi (Temminck et Schlegel) (Moravec et al. 1998), and $H$. mexicana Moravec et Fajer-Avila, 2000 from the swimbladder of the tetraodontiform fish Sphoeroides annulatus Jenyns of the Pacific coast of Mexico (Moravec and Fajer-Avila 2000). The features by which individual Huffmanela species are separated are apparent from the keys to species given by Moravec et al. (1998) and Moravec and Fajer-Avila (2000).

By their size, shape and general structure, the eggs of $H$. paronai somewhat resemble only those of $H$. japonica and H. mexicana (eggs of other Huffmanela spp. are much larger, their surface is spinous or they are of a different shape). However, in contrast to $H$. paronai, the eggs of $H$. japonica are markedly larger (58-69 × 26-30 $\mu \mathrm{m})$, located in the host's musculature. The eggs of $H$. mexicana are distinctly larger $(63-69 \times 30-33 \mu \mathrm{m})$ and are evenly distributed in the inner layer of the wall of the host's swimbladder. The host types and the geographical distribution should also be taken into account: while $H$. paronai occurs in fishes of the family Xiphiidae in the Ligurian Sea in Europe, $H$. japonica and $H$. mexicana are parasitic in the Mullidae in the 

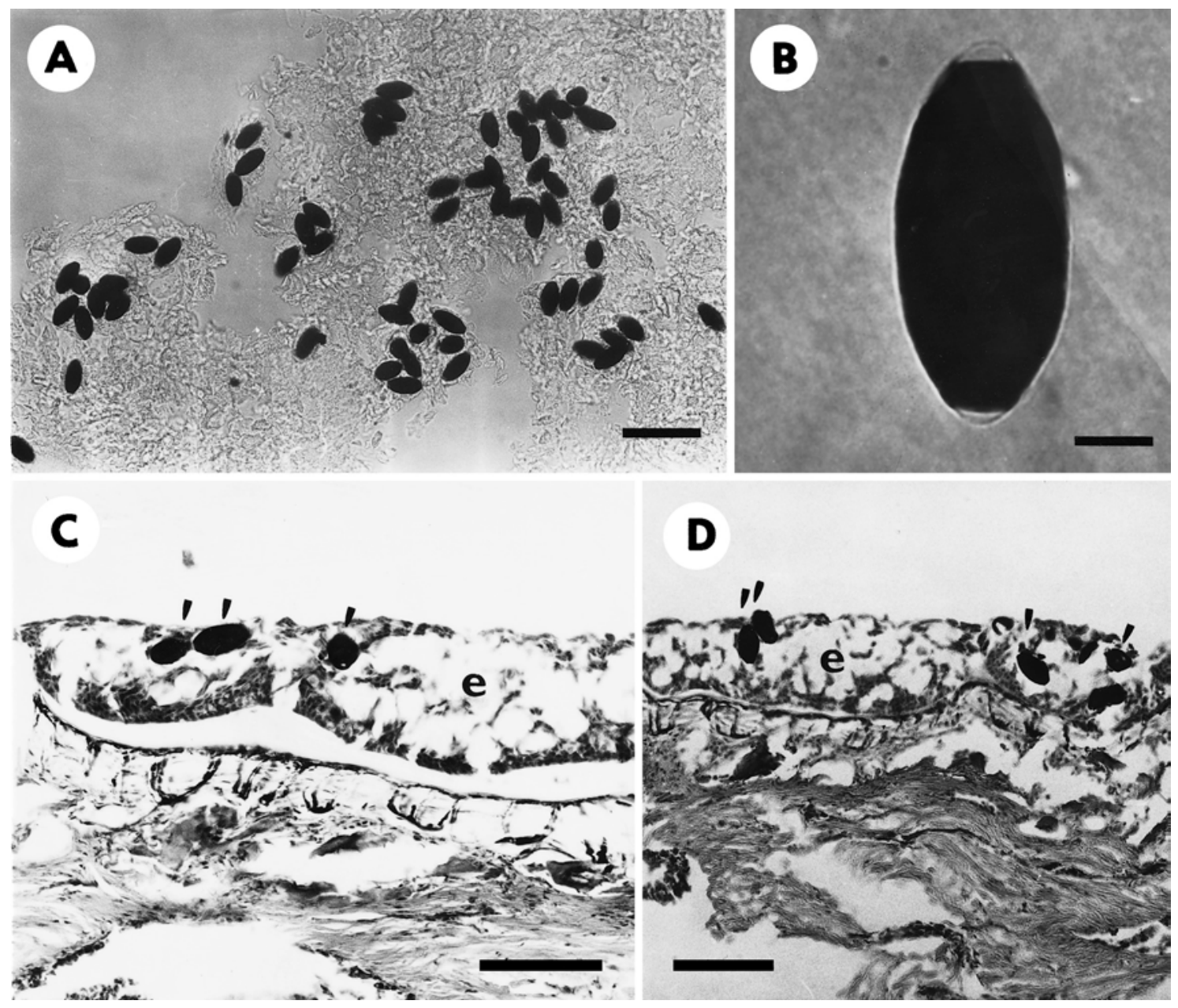

Fig. 2. Huffmanela paronai sp. n., micrographs of eggs. A-advanced eggs in a scraping of host epidermis (fresh mount); B - advanced egg (fresh mount); C, D - advanced eggs (arrowheads) in epidermis (e) (histological sections). Scale bars: A, C, D $=100 \mu \mathrm{m} ; \mathrm{B}=10 \mu \mathrm{m}$.

Inland Sea of Japan and in the Tetraodontidae in the Pacific Ocean in Mexico, respectively. Huffmanela paronai has the smallest eggs compared to all of its congeners.

It appears that the site of infection in the host is a diagnostic characteristic of each respective Huffmanela species and can be considered as a supplementary specific feature in this genus (Moravec 2000). To date, only one other Huffmanela species, H. carcharhini, is known to have its eggs located in the host's skin. However, the eggs of the former are spinous and almost double-sized (90-105 × 42-54 $\mu \mathrm{m})$ (Moravec 1987); moreover, $H$. carcharhini is a parasite of sharks.

In spite of some recent attempts to experimentally study the life cycle of $H$. huffmani (see Cox 1998, Moravec 2000), the biology of Huffmanela spp. remains unknown. Apparently, adult females lay their eggs in the host's tissue in an early stage where they continue to develop; the egg shell (its central chitinous layer) becomes gradually thicker and darkens and a larva develops inside the egg (Moravec and Fajer-Avila 2000).

Cox (1998) and Moravec (2000) experimentally demonstrated that $H$. huffmani eggs, located in the host's swimbladder, were liberated into the external environment only after the original hosts were ingested by piscivorous animals (e.g., predatory fish) through the digestive tract of which the eggs were passaged. The same way of liberating eggs can be assumed in those Huffmanela spp. in which the eggs are located in the host's musculature, intestinal serosa or swimbladder wall; all these species are parasitising relatively small fish species. On the other hand, $H$. carcharhini and $H$. paronai, the eggs of which occur in the epidermis or gill epithelium, are parasitic in large-sized host (sharks, swordfishes), which are preyed upon by other animals only rarely. Observations on $H$. paronai, and the same can be expected in $H$. carcharhini, suggest that the eggs 


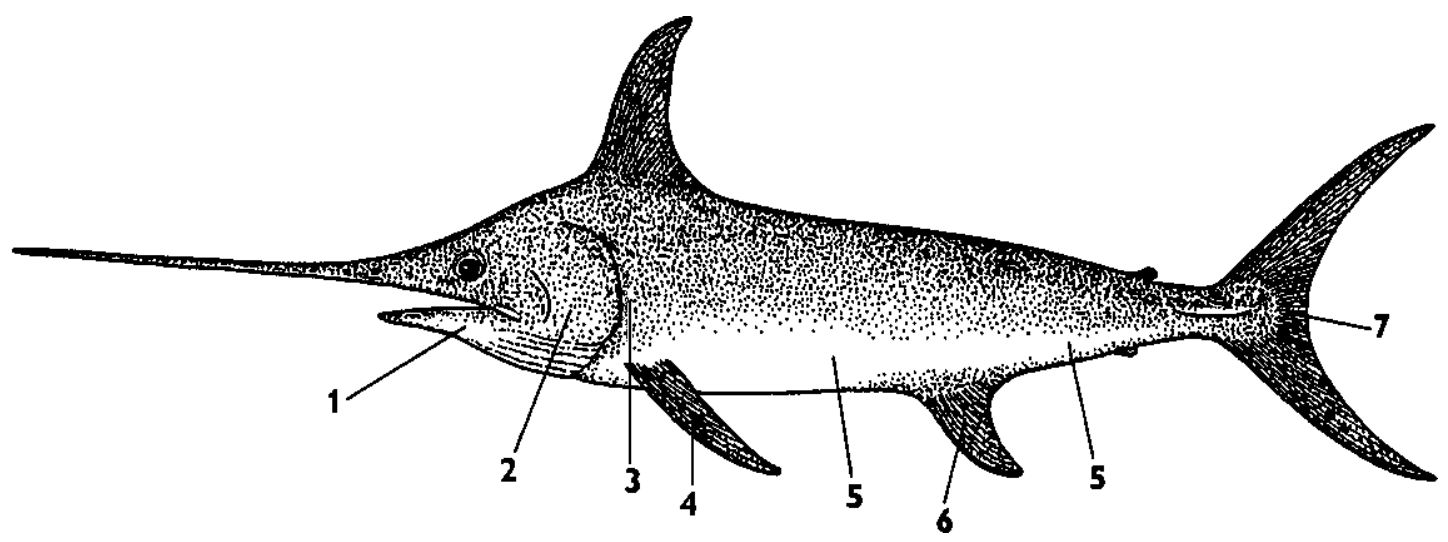

Fig. 3. Scheme of swordfish body with sites of the most frequent occurrence of Huffmanela paronai eggs ("black spots"): 1 - lower jaw; 2 - gill cover; 3 - thin skin behind gill cover; 4 - pectoral fin; 5 - lower half of body; 6 - anal fin; 7 - caudal fin.

are released into the environment during the normal turnover of epithelial cells (creeping of the host's several-layered epidermis). A similar mode of releasing the eggs occurs, for example, in another trichinelloid nematode, the capillariid Paratrichosoma recurvum (Solger, 1877), a skin-invading parasite of crocodiles in Mexico (Solger 1877, 1933, Moravec and VargasVázquez 1998). Free, embryonated Huffmanela eggs are not directly infective to a new definitive host, as was experimentally demonstrated in $H$. huffmani, and, undoubtedly, there is an obligatory intermediate host involved in the life cycles of these parasites (Moravec 2000).
Acknowledgements. The authors thank all fishermen of the Sanremo harbour for their collaboration, Drs. Walter Mignone and Claudio Pellegrino of the Istituto Zooprofilattico Sperimentale del Piemonte, Liguria e Valle D'Aosta for their help in the preliminary examination of the nematode eggs. We also thank Prof. Lidia Orsi Relini at DIP. TE. RIS., University of Genoa, director of the research programme on large pelagic fish in the Ligurian Sea, for giving an opportunity to sample the present material, Dr. Eileen Harris of the Natural History Museum in London for her professional advice, and Mrs. Irena Husáková, Institute of Parasitology, ASCR, in České Budějovice, for her technical assistance. This study was supported by a grant from the Italian Ministry of the Agricultural and Forestry Policy to Prof. L. Orsi Relini and by grant no. 524/97/0009 from the Grant Agency of the Czech Republic.

\section{REFERENCES}

COX M.K. 1998: The distribution and life cycle of Huffmanela huffmani (Nematoda: Trichosomoididae). M.Sc. thesis, Southwest Texas State University, San Marcos, Texas, USA, 52 pp.

HUFFMAN D.G., MORAVEC F. 1988: First description of adult Huffmanela huffmani Moravec, 1987 (Nematoda: Trichosomoididae) from the swimbladder of centrarchid fishes of the upper San Marcos River, central Texas. Folia Parasitol. 35: 227-234.

MacCALLUM G.A. 1925: Eggs of a new species of nematoid worm from a shark. Proc. U. S. Natl. Mus. 67: 1-2.

MacCALLUM G.A. 1926: Nematode eggs from the gill region of a shark, Carcharhinus milberti. Proc. U. S. Natl. Mus. 70: 1-2.

MORAVEC F. 1987: Revision of capillariid nematodes (subfamily Capillariinae) parasitic in fishes. Studie ČSAV No. 3. Academia, Praha, $141 \mathrm{pp}$.

MORAVEC F. 2000: Trichinelloid Nematodes Parasitic in Cold-blooded Vertebrates. Academia, Praha - in press.

MORAVEC F., CAMPBELL B.G. 1991: A new Huffmanela species, H. schouteni sp. n. (Nematoda: Trichosomoidi- dae) from flying fishes in Curaçao. Folia Parasitol. 38: 2932.

MORAVEC F., FAJER-AVILA E. 2000: A new Huffmanela species, H. mexicana $\mathrm{n}$. sp. (Nematoda: Trichosomoididae), from the marine fish Sphoeroides annulatus in Mexico. J. Parasitol. - in press.

MORAVEC F., KOUDELA B., OGAWA K., NAGASAWA K. 1998: Two new Huffmanela species, H. japonica n. sp. and H. shikokuensis $\mathrm{n}$. sp. (Nematoda: Trichosomoididae), from marine fishes in Japan. J. Parasitol. 84: 589-593.

MORAVEC F., VARGAS-VÁZQUEZ J. 1998: First description of the male and redescription of the female of Paratrichosoma recurvum (Nematoda: Capillariidae), a skininvading parasite of crocodiles in Mexico. Parasitol. Res. 84: 499-504.

PRIEBE K. 1976: Zur Schwarzfleckigkeit der Muskulatur der afrikanischen Hundszunge Cynoglossus browni Chabanaud 1949 verursacht durch Nematodeneier-Ansammlungen. Die Fleischwirtschaft 56: 520-521.

SCHOUTEN H., SURIEL-SMEETS R.M., KIBBELAAR M.A. 1968: The simultaneous occurrence of ova resem- 
bling Dicrocoelium dendriticum or Capillaria hepatica in the stools of inhabitants of Curaçao. Trop. Geogr. Med. 20: $271-275$.

SOLGER B. 1877: Ueber eine neue Species von Trichosoma R. Arch. Naturgesch. 43: 19-23.

SOLGER B. 1933: Ein vergessener Parasit (Trichosoma recurvum) als Ursache von "creeping disease"; ein literatur-historisches Beitrag zur vergleichenden Pathologie der Haut der Wirbeltiere. Dermatol. Wochenschr. 96: 476-477.
SURIEL-SMEETS R.M., SCHOUTEN H. 1972: The simultaneous occurrence of ova resembling Dicrocoelium dendriticum and Capillaria hepatica in the stools of inhabitants of Curaçao. II. Identification of the Dtrematode: Didymozoon sp. Trop. Geogr. Med. 24: 192193.

van BANNING P. 1980: The occurrence of black spots in the tongue sole, Cynoglossus browni Chabanaud, due to nematode eggs (Capillaria spinosa) previously described in the shark Carcharhinus milberti Müller \& Henle. J. Fish Biol. 17: 305-309.

Accepted 20 July 2000 